Назарова О. Ю., к.е.н., доцент Харківський національний університет імені В. Н. Каразіна м. Харків, Украӥна

Чатченко Т. В., к.е.н., доцент Харківський національний університет імені В. Н. Каразіна м. Харків, Украӥна DOI: https://doi.org/10.30525/978-9934-26-028-5-45

\title{
ОСОБЛИВОСТІ ДЕМОГРАФІЧНОЇ СИТУАЦІЇ В УКРАЇНІ НА СУЧАСНОМУ ЕТАПI
}

Економічний розвиток будь-якої держави грунтується на багатьох факторах, одним із головних вважається наявність достатньої кількості та належної якості трудових ресурсів, що визначаються загальною чисельністю населення та процесами його відтворення. Сучасна демографічна ситуація в Україні має загострений характер, як і в більшості розвинених країн Свропи, та переходить до якісного нового типу відтворення. 
Слід зазначити, що населенню України притаманні несприятливі тенденції та негативні зрушення у структурах населення. Так, як свідчать офіційні статистичні дані в країні у 1989-2019 pp. рівень смертності значно перевищує рівень народжуваності, тобто відбувається процес депопуляції (рис. 1). Можна простежити, що чисельність населення починаючи 3 1993 року набуло сталої тенденції до спаду. Найбільш різким та помітним зменшенням вважається 2014 рік, що пов'язано 3 нестабільною політичною ситуацією в окремих регіонах країни.

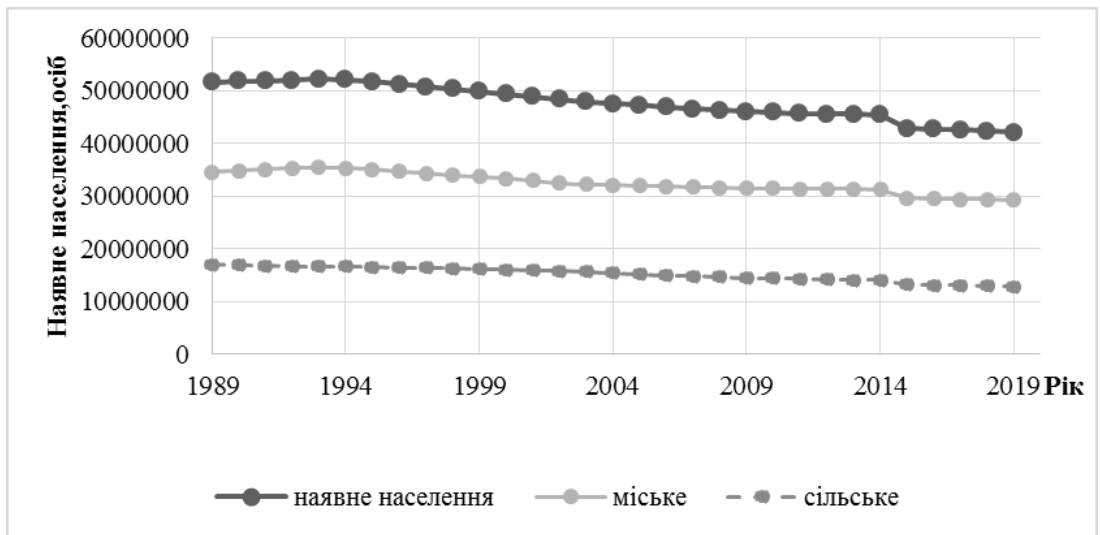

Рис. 1. Наявне населення України за 1989-2019 роки

Джерело: побудовано авторами на основі даних [1] (3 2015 року без урахування тимчасово окупованої території АР Крим, м. Севастополь та частини зони проведення АТО).

Аналіз статево-вікової структури населення передбачає побудову піраміди та розрахунок навантаження дітьми та людьми похилого віку на працездатне населення. Необхідність даного процесу полягає в тому, щоб вияснити економічну спроможність населення до належного забезпечення непрацездатного населення (рис. 2).

Відзначимо, що в Україні панує тенденція до переваги кількості жінок над чоловіками: у 2019 р. відсоток жіночого населення складав $53,66 \%$, в той час, як частка чоловіків була $46,34 \%$ [2]. Проте, згідно з даними про статево-віковий розподіл, 
хлопчиків народжується більше ніж дівчат (у 2019 р. розподіл за статтю серед дітей до 1 року мав наступну структуру: чоловіча стать - 51,61\%, жіноча - 48,39\%). Перевага кількості жіночого населення над чоловічим починається висліджуватися у віці 36-37 років. Така проблема скорочення чоловічого населення $є$ наслідком виникнення в цьому віці захворювань пов'язаних 3 важкою трудовою діяльністю та шкідливих умов праці, смертність у ДТП, надзвичайних ситуаціях, воєнних операціях у чоловіків вища ніж серед жінок.

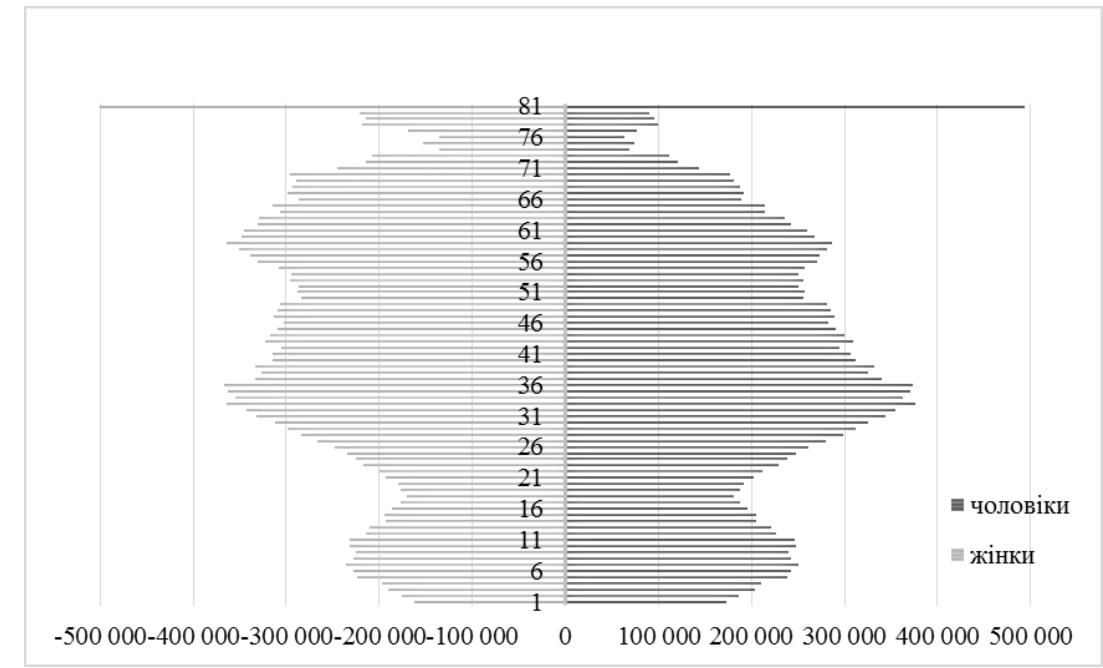

\section{Рис. 2. Статево-вікова піраміда наявного населення України у 2019 р.}

Джерело: побудовано авторами на основі даних [1]

Розрахунки демонструють, що населення України належатиме до регресивного типу, це означає, що старшого покоління більше ніж дітей, тобто відбувається старіння нації, що негативно впливає на трудовий потенціал країни в цілому.

На чисельність населення безпосередньо впливає й природний приріст населення, що визначається різницею між кількістю новонароджених та кількістю померлих. Отже, динаміка та 
тенденції природного руху населення прямо пропорційні змінам показників смертності та народжуваності.

На основі даних Державної служби статистики про кількість народжених розглянемо структуру народжених в Україні за 2019 р. за регіонами, таким чином, щоб виявити області 3 найбільшим потенціальним трудовим ресурсом (рис. 3).

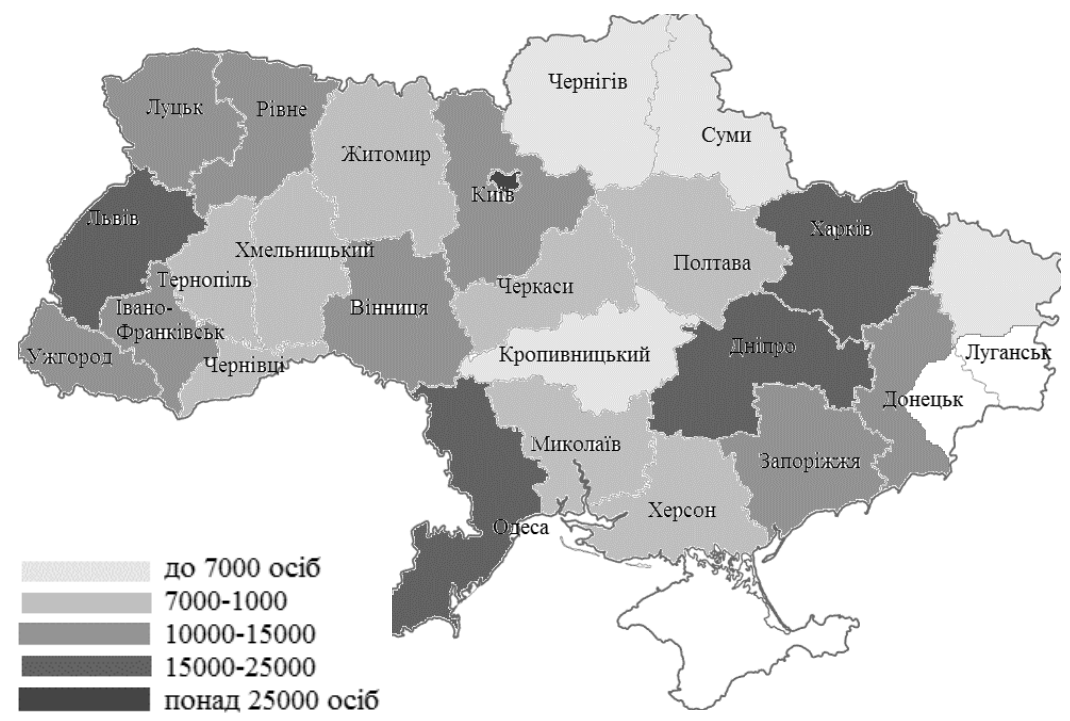

\section{Рис. 3. Розподіл кількості народжених по областям України за 2019 р.}

Джерело: побудовано авторами на основі даних [1]

На картограмі проілюстровано, що найбільше народжується дітей у м. Києві - майже 10,5\% від загальної кількості народжених в Україні, у той час найменший показник народжуваності в Луганській області - 1,6\%.

Загальні коефіцієнти у 2019 році склали: народжуваності 7,35\%, смертності-13,827\%.

Найвищі показники смертності було зафіксовано в трьох регіонах України: Дніпропетровська область - 50929 осіб, 
Донецька - 41087 осіб та Харківська - 40611 осіб. У цих областях велика кількість померлих є наслідком, перш за все, екологічного забруднення навколишньої середи, адже тут розташована більша частина великих підприємств, заводів, які щодня роблять викиди шкідливих речовин в атмосферу, воду та грунт.

Забруднення екології в даних областях 3 віком викликає у населення різні хвороби та патології, що сприяють на життєдіяльність та скорочення тривалості життя. Хвороби сердечно-судинної системи, новоутворення, цереброваскулярні хвороби - основні причини смерті в цих регіонах, що виникають у людей віком 35-60 років.

Моніторинг Всесвітньої організації охорони здоров'я показав, що Україна посідає 96-те місце серед 176 країн світу за показником витрат держави на охорону здоров'я.

Економічний прогрес держави не може існувати окремо без трудових ресурсів. Всупереч розвитку країни, демографічна ситуація перебуває в жахливому стані. В Україні державне регулювання на відміну від європейських країн, на цей час не має результатів щодо покращення i тому на сьогодні актуальне питання - демографічна криза. Досить помітно, що через політично-економічну ситуацію в країні, покращення демографічних показників - це дуже важке питання, вирішення якого потребує чималих зусиль.

\section{Література:}

1. Демографічний паспорт України URL : http://database.ukrcensus.gov.ua/M ULT/Dialog/statfile_c.asp (дата звернення: 11.01.2021).

2. Державна служба статистики України. URL : http://www.ukrstat.gov.ua/ (дата звернення: 11.01.2021).

3. Демографічна політика України. URL : http://pidruchniki.com/10310208/ek ologiya/demografichna_politika_ukrayini/ (дата звернення: 11.01.2021).

4. База даних OOH. URL : http://www.un.org/en/documents/index.html (дата звернення: 11.01.2021).

5. Назарова А.Ю. Особенности демографической политики в Украине. Тhe international scientific conference «Development of social and economic systems in a global competitive environment». February 26, 2016. Chisinau, The republic of Moldova, 2016. 302 p. P. 198-200. 
6. Назарова О.Ю. Сучасні фактори і тенденції розвитку демографічних процесів. Вісник Харківського Національного університету імені В.Н. Каразіна. 2011. № 970. C. 286-290. 